\title{
Yield and Composition of Buckwheat Biomass Relative to Forage Use
}

\author{
Harbans L. Bhardwaj ${ }^{1} \&$ Anwar A. Hamama ${ }^{1}$ \\ ${ }^{1}$ Agricultural Research Station, Virginia State University, Petersburg, Virginia, USA \\ Correspondence: Harbans L. Bhardwaj, Agricultural Research Station, Virginia State University, Petersburg, \\ Virginia 23806, USA. Tel: 1-804-524-6723. Fax: 1-804-524-5950. E-mail: hbhardwaj@vsu.edu
}

\author{
Received: May 9, $2020 \quad$ Accepted: June 11, $2020 \quad$ Online Published: July 15, 2020 \\ doi:10.5539/jas.v12n8p129 URL: https://doi.org/10.5539/jas.v12n8p129
}

The research was financed by Virginia Agricultural Council, and Virginia State University and US Department of Agriculture (NIFA/Evans-Allen Program).

This paper was contribution of Virginia State University, Agricultural Research Station. Use of any trade names or vendors does not imply approval to the exclusion of other products or vendors that may also be suitable.

\begin{abstract}
Buckwheat (Fagopyrum esculentum Moench), a pseudo-cereal, has potential as a forage crop, cover crop, grain crop for animal feed and human food, honey bee crop, and a smother crop for weed suppression. Even though, buckwheat has a long history in Virginia, currently this crop is almost non-existent in this area. The New Crops Program of Virginia State University started researching buckwheat in 2015 as an alternate food crop and as a plant to support honey bees. These studies led into evaluation of buckwheat as a forage crop. Approximately 30-day old buckwheat tissue of two cultivars (Koto and Mancan), planted on June 22 or July 20 during 2015, yielded 4784 pounds fresh weight and 1000 pounds dry matter per acre. Buckwheat biomass contained approximately 21 percent protein and approximately 6 percent oil. Quality of buckwheat forage compared well with literature values for alfalfa hay, perennial peanut, soybean, white lupin, and Tepary bean forage.
\end{abstract}

Keywords: Fagopyrum esculentum, forages, protein concentration, oil concentration, ADF, NDF, minerals, alternate crops

\section{Introduction}

Buckwheat (Fagopyrum esculentum Moench, Family Polygonaceae) is considered a pseudo-cereal. Buckwheat has a reputation for growing on poor soils and thriving in a wide variety of soils. Even small amounts of fertilizer are known to considerably enhance buckwheat performance in low fertility soils. Buckwheat can be used as a forage crop, cover crop, grain crop for animal feed and human food, honey bee crop, and a smother crop for weed suppression. Buckwheat is an extremely short-duration crop and has great potential when "normal" crops fail. It improves the soil and suppresses weeds; needs very little attention during the growing season; makes a great rotation crop; often grows well on low-fertility land; is a high-yield crop; and can be planted as late as mid-July in many areas and is fast growing - 70 days from planting to harvest full. Fertilizer needs of buckwheat are limited, producing savings in labor, fuel and chemical inputs.

Buckwheat has been grown in Virginia since late 1700s (Thomas Jefferson's letter to George Washington dated May 14, 1794 indicated his interest in buckwheat as a rotation crop https://founders.archives.gov/documents/ washington/05-16-02-0055). However, today the crop is almost non-existent in Virginia. Even though, literature indicates that buckwheat can be used as a forage (Cheng, 2018; Amelchanka et al., 2010; Mariotti et al., 2016; $\mathrm{Mu}$ et al., 2019), information about use of buckwheat as a summer forage crop in Virginia and adjoining states is non-existent. Objectives of the current study were to determine buckwheat forage yield following different planting dates and to characterize its' nutritional value for forage use.

\section{Materials and Methods}

\subsection{Plant Material}

The plant material for this study consisted of two buckwheat cultivars: black-hulled Koto and brown-hulled Mancan. Koto buckwheat became available to growers in the Northeast United States for the first time in 2002. It was developed in a joint project between Cornell University and Kade Research, and funded by Birkett Mills. 
Koto was in commercial trials in New York annually from 1999 through 2001. It has out yielded Manisoba by 13\% on average and is more stress tolerant (http://www.hort.cornell.edu/bjorkman/lab/buck/guide/varieties.php). Mancan buckwheat was developed by Agriculture and Agri-Food Canada in Morden, Manitoba (Izydorczyk et al., 2014).

\subsection{Production and Sampling}

An experiment with Mancan and Koto buckwheat varieties was planted three times during 2015 in the field [Abel sandy loam-Fine Loamy mixed thermic Aquatic Hapridult soil with $6.5 \mathrm{pH}, 1.5 \%$ organic matter, and $\mathrm{P}, \mathrm{K}$, $\mathrm{Mg}$, and Ca concentrations (mg/kg) 77, 54, 68, and 395, respectively] at Randolph Farm of Virginia State University in Ettrick, Virginia (USA). The planting dates were June 22, July 20, and August14. These plots didn't receive any fertilizer or irrigation. The field design was a RCBD with four replications. Each plot consisted of four rows (37.5 cm apart) with approximately 100 seeds planted in $2.5 \mathrm{~m}$ row length. One sample (approximately $40 \mathrm{~cm}$ row length from the one of the middle rows) was harvested from each plot for data collection. Samples of biomass were collected about 30 days after planting.

\subsection{Data Collection}

Fresh and dry matter were recorded in grams and then converted to $\mathrm{kg} / \mathrm{ha}$ for all plots. Concentrations of $\mathrm{N}$, sugars (Sucrose, fructose, glucose, raffinose, stachyose, and verbascose), oil, ADF, NDF, B, P, K, Ca, Cu, Fe, Mg, $\mathrm{Mn}, \mathrm{Na}, \mathrm{S}$, and $\mathrm{Zn}$ were determined, only for first and second plantings, using AOAC methods (AOAC, 2016) and by using established commercial equipment by Waypoint Analytical Laboratory (Richmond, Virginia, USA). Total protein concentration was calculated by multiplying $\mathrm{N}$ content with protein factor 6.25 .

Oil and sugar concentrations were determined in the Common Laboratory of Agricultural Research Station of Virginia State University. The oil was extracted from ground buckwheat dry material $(5 \mathrm{~g})$ three times at room temperature by homogenization for $2 \mathrm{~min}$ in $20 \mathrm{~mL}$ hexane/isopropanol (3:2, v/v) with a Biospec Model 985-370 Tissue Homogenizer (Biospec Products, Inc. Racine, WI, USA) and centrifuged at $4000 \mathrm{~g}$ for $5 \mathrm{~min}$, as described by Hamama et al. (2003). The three extractions were combined and the hexane-lipid layer was separated from the combined extract after shaking with $10 \mathrm{~mL}$ of $1 \%$ solution of equal amounts of $\mathrm{CaCl}_{2}$ and $\mathrm{NaCl}$ in $50 \%$ methanol. The hexane lipid layer was removed by aspiration and dried over anhydrous $\mathrm{Na}_{2} \mathrm{SO}_{4}$. The oil percentage ( $\mathrm{g} / 100 \mathrm{~g}$ dry basis) was determined gravimetrically after drying under vacuum at $40{ }^{\circ} \mathrm{C}$ and stored under nitrogen at $-10{ }^{\circ} \mathrm{C}$ until analysis.

Sugars were extracted from ground buckwheat sample $(1 \mathrm{~g})$ and analyzed by HPLC following the methods optimized by Johansen et al. (1996). Sugars in the extracts were identified by comparing their retention times with standard sugars. For quantification, trehalose was used as internal standard and the sugar concentration was expressed as $\mathrm{g} / 100 \mathrm{~g}$ meal (Bhardwaj \& Hamama, 2016).

\subsection{Statistical Analysis}

All data were analyzed as a Randomized Complete Block Design using version 9.1 of SAS (SAS Institute, Inc., 2014) using ANOVA with 5\% level of significance. Composition traits of buckwheat from this study were compared to literature values for alfalfa hay, perennial peanut, and soybean forage.

\section{Results and Discussion}

\subsection{Fresh and Dry Yields}

Results indicated that buckwheat varieties and planting dates contributed significantly towards variation for fresh yield and several compositional traits (Table 1). In general, interactions between varieties and planting dates were not significant. Details of results from this preliminary study on buckwheat grown in Virginia during 2015 along with values for other forages from literature, are presented below: 
Table 1. ANOVA (Mean squares) for yield and composition traits of buckwheat grown during 2015 at Ettrick, Virginia (USA)

\begin{tabular}{llll}
\hline \multirow{2}{*}{ Source } & \multicolumn{3}{c}{ Mean squares $^{1}$} \\
\cline { 2 - 4 } & Variety $^{1}$ & Planting date $^{1}$ & Variety* Planting date \\
\hline Fresh yield kg/ha & $5659469^{* *}$ & $1841452^{*}$ & 748719 \\
Dry yield kg/ha & 24603261 & 17472547 & 5785942 \\
Oil & $3.05^{* *}$ & 0.34 & 0.06 \\
Protein & 1.89 & 13.88 & 0.77 \\
$\mathrm{ADF}$ & 37.52 & 8.56 & 0.14 \\
$\mathrm{NDF}$ & 28.09 & 9.61 & 2.10 \\
Sucrose & 0.18 & 0.36 & 0.38 \\
Fructose & 0.06 & $9.99^{* *}$ & 0.79 \\
$\mathrm{Glucose}$ & 1.36 & $71.21^{* *}$ & 8.84 \\
$\mathrm{P}$ & 0.003 & $0.342^{* *}$ & 0.001 \\
$\mathrm{~K}$ & 0.016 & $0.566^{* *}$ & 0.124 \\
$\mathrm{Ca}$ & 0.029 & $3.940^{* *}$ & 0.096 \\
$\mathrm{Mg}$ & 0.009 & $0.744^{* *}$ & 0.023 \\
$\mathrm{~S}$ & 0.000 & 0.001 & 0.001 \\
$\mathrm{Na}$ & 0.000 & $0.001 * *$ & 0.000 \\
$\mathrm{~B}$ & 4.000 & $90.25^{* *}$ & 0.250 \\
$\mathrm{Zn}$ & 16.000 & $289.00^{* *}$ & 0.250 \\
$\mathrm{Mn}$ & 0.062 & 203.06 & 18.06 \\
$\mathrm{Fe}$ & 121.00 & $13689.00^{* *}$ & 552.25 \\
$\mathrm{Cu}$ & 0.062 & 0.062 & 0.062 \\
$\mathrm{Al}$ & 72.25 & 1640.25 & 961.00 \\
\hline
\end{tabular}

Note. ${ }^{1}$ Two buckwheat varieties (Mancan and Koto), three planting dates (June 22, July 20, and August 14).

*, **: Significant at 5 and 1 percent levels, respectively.

Table 2. Biomass traits of buckwheat grown during 2015 at Ettrick, Virginia (USA)

\begin{tabular}{|c|c|c|c|c|c|}
\hline \multirow{2}{*}{ Biomass trait } & \multicolumn{2}{|c|}{ Varieties $^{1}$} & \multicolumn{3}{|c|}{ Planting dates $^{2}$} \\
\hline & Koto & Mancan & June 22 & July 20 & August 14 \\
\hline Fresh yield $\mathrm{kg} / \mathrm{ha}$ & $5669 \mathrm{a}$ & $4697 \mathrm{~b}$ & $5642 \mathrm{a}$ & $5223 \mathrm{ab}$ & $4685 \mathrm{~b}$ \\
\hline Dry yield kg/ha & $1141 \mathrm{a}$ & 973 & $1149 \mathrm{a}$ & $1104 \mathrm{a}$ & $917 \mathrm{a}$ \\
\hline Oil* & $6.1 \mathrm{a}$ & $5.2 \mathrm{~b}$ & $5.77 \mathrm{a}$ & $5.48 \mathrm{a}$ & Not available \\
\hline Protein* & $21.1 \mathrm{a}$ & $20.4 \mathrm{a}$ & $21.7 \mathrm{a}$ & $19.8 \mathrm{a}$ & Not available \\
\hline $\mathrm{ADF}^{*}$ & $29.8 \mathrm{a}$ & $32.9 \mathrm{a}$ & $32.1 \mathrm{a}$ & $30.6 \mathrm{a}$ & Not available \\
\hline $\mathrm{NDF}^{*}$ & $37.1 \mathrm{a}$ & $39.7 \mathrm{a}$ & $39.2 \mathrm{a}$ & $37.6 \mathrm{a}$ & Not available \\
\hline Sucrose* & $1.4 \mathrm{a}$ & $1.6 \mathrm{a}$ & $1.39 \mathrm{a}$ & $1.69 \mathrm{a}$ & Not available \\
\hline Fructose* & $3.2 \mathrm{a}$ & $3.3 \mathrm{a}$ & $2.49 \mathrm{~b}$ & $4.07 \mathrm{a}$ & Not available \\
\hline Glucose* & $7.6 \mathrm{a}$ & $8.2 \mathrm{a}$ & $10.01 \mathrm{a}$ & $5.80 \mathrm{~b}$ & Not available \\
\hline Phosphorus* & $0.53 \mathrm{a}$ & $0.50 \mathrm{a}$ & $0.66 \mathrm{a}$ & $0.37 \mathrm{~b}$ & Not available \\
\hline Potassium* & $2.84 \mathrm{a}$ & $2.78 \mathrm{a}$ & $3.00 \mathrm{a}$ & $2.62 \mathrm{~b}$ & Not available \\
\hline Calcium* & $2.40 \mathrm{a}$ & $2.31 \mathrm{a}$ & $2.85 \mathrm{a}$ & $1.86 \mathrm{~b}$ & Not available \\
\hline Magnesium* & $1.22 \mathrm{a}$ & $1.17 \mathrm{a}$ & $1.41 \mathrm{a}$ & $0.99 \mathrm{~b}$ & Not available \\
\hline Sulfur* & $0.25 \mathrm{a}$ & $0.25 \mathrm{a}$ & $0.26 \mathrm{a}$ & $0.25 \mathrm{a}$ & Not available \\
\hline Sodium** & $0.04 \mathrm{a}$ & $0.04 \mathrm{a}$ & $0.05 \mathrm{a}$ & $0.03 \mathrm{~b}$ & Not available \\
\hline Boron** & $29.0 \mathrm{a}$ & $28.0 \mathrm{a}$ & $30.9 \mathrm{a}$ & $26.1 \mathrm{~b}$ & Not available \\
\hline Zinc** & $35.6 \mathrm{a}$ & $33.6 \mathrm{a}$ & $38.9 \mathrm{a}$ & $30.4 \mathrm{~b}$ & Not available \\
\hline Manganese** & $36.4 \mathrm{a}$ & $36.5 \mathrm{a}$ & $32.9 \mathrm{a}$ & $40.0 \mathrm{a}$ & Not available \\
\hline Iron $* *$ & $149 \mathrm{a}$ & $144 \mathrm{a}$ & $176 \mathrm{a}$ & $117 \mathrm{~b}$ & Not available \\
\hline Copper** & $9.00 \mathrm{a}$ & $8.87 \mathrm{a}$ & $9.00 \mathrm{a}$ & $8.87 \mathrm{a}$ & Not available \\
\hline Aluminum** & $102 \mathrm{a}$ & $106 \mathrm{a}$ & $114 \mathrm{a}$ & $94 \mathrm{a}$ & Not available \\
\hline
\end{tabular}

Note. ${ }^{1}$ Means based on three planting dates and four replications; ${ }^{2}$ Means based on two varieties and two replications.

*: Percentage values on dry matter basis; **: Values as parts per million. 
Table 3. Composition traits of buckwheat and crops relative to forage potential

\begin{tabular}{|c|c|c|c|c|}
\hline Biomass trait & $\begin{array}{l}\text { Buckwheat grown } \\
\text { at VSU during } 2015\end{array}$ & Alfalfa hay ${ }^{1}$ & Perennial peanut hay ${ }^{1}$ & Soybean forage $^{2}$ \\
\hline Oil* & 5.6 & Not available & Not available & 6.1 \\
\hline Protein* & 20.8 & 19 & 14 & 19.8 \\
\hline $\mathrm{ADF}^{*}$ & 31.4 & 32 & 32 & 38.2 \\
\hline NDF* & 38.4 & 40 & 42 & 38.2 \\
\hline Sucrose* & 1.5 & Not available & Not available & Not available \\
\hline Fructose* & 3.28 & Not available & Not available & Not available \\
\hline Glucose* & 7.91 & Not available & Not available & Not available \\
\hline Phosphorus* & 0.52 & 0.2 & 0.2 & Not available \\
\hline Potassium* & 2.81 & 1.8 & 1.4 & Not available \\
\hline Calcium* & 2.36 & 1.3 & 1.3 & Not available \\
\hline Magnesium* & 1.19 & 0.4 & 0.5 & Not available \\
\hline Sulfur* & 0.25 & Not available & Not available & Not available \\
\hline Sodium** & 0.04 & Not available & Not available & Not available \\
\hline Boron** & 28.5 & Not available & Not available & Not available \\
\hline Zinc** & 34.6 & 30 & 34 & Not available \\
\hline Manganese ${ }^{* *}$ & 36.4 & Not available & Not available & Not available \\
\hline Iron** & 146 & Not available & Not available & Not available \\
\hline Copper** & 8.94 & 12 & 6 & Not available \\
\hline Aluminum** & 104 & Not available & Not available & Not available \\
\hline
\end{tabular}

Note. ${ }^{1}$ From Meyer et al. (2010); ${ }^{2}$ From Lundray et al. (2008).

*: Percentage values on dry matter basis; **: Values as parts per million.

Biomass yield in these experiments averaged 4784 pounds fresh weight and 1000 pounds dry matter per acre. Biomass yield of KOTO variety was slightly superior to that of Mancan variety. Similarly, biomass yield from June planting was superior to that from late planting dates.

Buckwheat biomass contained approximately 21 percent protein and approximately 6 percent oil (Table 2). Values of various quality traits of buckwheat biomass are presented in Table 2. Concentrations of several forage quality traits in buckwheat forage was affected by planting date (Fructose, Glucose, $\mathrm{P}, \mathrm{K}, \mathrm{Ca}, \mathrm{Mg}, \mathrm{Na}, \mathrm{B}, \mathrm{Zn}$, and Fe). In general, earlier planting date of June 20 resulted in significantly higher values for these traits except for concentrations of fructose and $\mathrm{Mn}$ in which case the values from later planting date of July 20 were significantly higher than those from the earlier planting date of June 22. Despite these differences, we observe that forage quality of buckwheat forage, produced in Virginia, was acceptable.

A comparison of buckwheat forage with that of alfalfa, perennial peanut hay, and soybean is presented in Table 3. Buckwheat forage had higher protein concentration than other forages whereas oil concentration of buckwheat forage was lower than that in soybean forage. Both ADF and NDF concentrations in buckwheat forage were lower than those in all other forages. Concentrations of $\mathrm{P}, \mathrm{K}, \mathrm{Ca}, \mathrm{Mg}$, and $\mathrm{Zn}$ were higher in buckwheat forge as compared to those in alfalfa hay and perennial peanut hay. Concentration of $\mathrm{Cu}$ in buckwheat forage was intermediate between that of alfalfa hay and perennial peanut hay.

We have previously reported (Bhardwaj, 2013; Bhardwaj et al., 2010) forage quality of two new crops, Tepary bean (Phaseolus acutifolius A. Gray) and white lupin (Lupinus albus L.). Both of these are legume crops as compared to non-legume buckwheat. Tepary bean forage from 59 days old crop contained 21.4 percent protein, 37.5 percent ADF, 41.1 percent NDF, and 1.12 percent fat. Mean values of $\mathrm{P}, \mathrm{K}, \mathrm{S}, \mathrm{Ca}, \mathrm{Mg}$, and $\mathrm{Na}(\%$ dry matter) in tepary bean forage were $0.28,2.5,0.28,2.11,0.54$, and 0.05 , respectively. Mean values of $\mathrm{Fe}, \mathrm{Al}, \mathrm{Mn}$, $\mathrm{Cu}, \mathrm{Zn}$, and $\mathrm{B}\left(\mathrm{mg} \mathrm{kg}^{-1}\right)$ were $307,229,359,9.3,39.5$, and 20.9, respectively (Bhardwaj, 2013). White lupin forage during 2003-04 crop season (Approximately 180 days old) had a mean ADF content of 23.7 percent with a range of 17 to 41 percent and a mean crude protein content of 18.7 percent with a range of 13 to 29 percent (Bhardwaj et al., 2010). These results indicate that, in general, quality of buckwheat forage is acceptable and a potential use of this crop especially because buckwheat can be harvested in about 30 days and can be grown with minimal inputs. 
Based on these results, buckwheat forage seems to be a desirable forage. There is a lack of crop options for planting during late summer if/when summer crops such as corn and soybean fail due to drought. Buckwheat has tremendous potential for successful production during this period especially as a short-season forage crop. These results are only from one year and would need to be repeated over years and locations to critically characterize the potential of buckwheat as a forage crop.

El-Nashaar et al. (2009) indicated that concentrations of Al, P, K, and S (ppm) in switchgrass (44 to 111, 1297 to 5656,6481 to 15806,467 to 1133 , respectively) are suitable, generally, for its thermochemical conversion to ethanol. Berchem et al. (2017) indicated that sucrose content in corn stalks varied from 0.7 to $11.5 \%$ with an average of $7.05 \%$. Concentrations of $\mathrm{Al}, \mathrm{P}, \mathrm{K}$, and $\mathrm{S}$ (ppm) in buckwheat biomass, in our study, were (104, 5200, 28100 , and 2500, respectively) are quite comparable to those reported by El-Nashaar et al. (2009). Sucrose concentration of buckwheat biomass in our study was $1.5 \%$. Based on these observations, we suggest that buckwheat biomass may also be a potential feed stock for bio-ethanol. This aspect needs to be explored further.

Our results indicate that buckwheat could be developed as a short-season, summer forage crop in Virginia and the Mid-Atlantic region of United States. This crop could also be a great help to bees as it could provide an alternative source of nectar. Seemingly, buckwheat can be grown as a nectar source and then harvested as a forage upon cessation of flowering. Additionally, buckwheat biomass may also have potential as an ethanol feedstock similar to use of corn stover.

\section{Conclusions}

This study indicated that buckwheat (Fagopyrum esculentum Moench, Family Polygonaceae) is a potential forage crop in mid-Atlantic region of the United States of America since agro-climatic conditions in Virginia are representative of those in mid-Atlantic region. Additionally, buckwheat as a summer crop could also support bees and other pollinating insects by providing a nectar source. Buckwheat biomass may also have potential as a feedstock for synthesis of bio-ethanol.

\section{Acknowledgements}

Authors are thankful to Virginia Agricultural Council for supporting this research with financial assistance. Authors are thankful to Virginia State University and US Department of Agriculture (NIFA/Evans-Allen Program) for their support of this study.

\section{References}

Amelchanka, S. L., Kreuzer, M., \& Leiber, F. (2010). Utility of buckwheat (Fagopyrum esculentum Moench) as feed: Effects of forage and grain on in vitro ruminal fermentation and performance of dairy cows. Animal Feed Science and Technology, 155, 111-121. https://doi.org/10.1016/j.anifeedsci.2009.10.007

AOAC (Association of Official Analytical Chemists). (2016). Official Methods of Analysis (20th ed.). AOAC, Arlington, VA. Retrieved from http://www.aoac.org/aoac_prod_imis/AOAC/AOAC_Member/PUBSCF/ OMACF/OMAP_M.aspx

Berchem, T., Roiseux, O., Vanderghem, C., Boisdenghien, A., Foucart, G., \& Richel, A. (2017). Corn stover as feedstock for the production of ethanol: Chemical composition of different anatomical fractions and varieties. Biofuels, Bioproducts \& Biorefining, 11, 430-440. https://doi.org/10.1002/bbb.1755

Bhardwaj, H. L. (2013). Preliminary Evaluation of Tepary Bean (Phaseolus acutifolius A. Gray) as a Forage Crop. Journal of Agricultural Science, 5, 160-166. https://doi.org/10.5539/jas.v5n7p160

Bhardwaj, H. L., \& Hamama, A. A. (2016). Cultivar, planting date, and row spacing effects on Mungbean seed Composition. Journal of Agricultural Science, 8, 26-32. https://doi.org/10.5539/jas.v8n10p26

Bhardwaj, H. L., Starner, D. E., \& van Santen, E. (2010). Preliminary evaluation of white lupin (Lupinus albus L.) as a forage crop in the mid-Atlantic region of the United States of America. Journal of Agricultural Science, 2, 13-17. https://doi.org/10.5539/jas.v2n4p13

Cheng, A. (2018). Review: Shaping a sustainable food future by rediscovering long-forgotten ancient grains. Plant Science, 269, 136-142, https://doi.org/10.1016/j.plantsci.2018.01.018

El-Nashaar, H. M., Banowetz, G. M., Griffith, S. M., Casler, M. D., \& Vogel, K. P. (2009). Genotypic variability in mineral composition of switchgrass. Bioresource Technology, 100, 1809-1814. https://doi.org/10.1016/ j.biortech.2008.09.058 
Izydorczyk, M. S., McMillan, T., Bazin, S., Kletke, J., Dushnicky, L., \& Dexter, J. (2014). Canadian buckwheat: A unique, useful and under-utilized crop. Can. J. Plant Sci., 94, 509-524. https://oi.org/10.4141/ CJPS2013-075

Johansen, H. N., Gilts, V., \& Knudsen, K. E. N. (1996). Influence of Extraction Solvent and Temperature on the Quantitative Determination of Oligosaccharides from Plant Materials by High-Performance Liquid Chromatography. J. Agric. Food Chem., 44, 1470-1474. https://doi.org/10.1021/jf950482b.

Lundray, D. R., Ridley, W. P., Meyer, J. J., Riordan, S. G., Nemeth, M. A., Trujillo, W. A., ... Sorbet, R. (2008). Composition of grain, forage, and processed fractions from second-generation glyphosate-tolerant soybean, MON 89788, is equivalent to that of conventional soybean (Glycine max L.). J. Agric. Food Chem., 56, 4611-4622. https://doi.org/10.1021\%2Fjf073087h

Mariotti, M., Masoni, A., \& Arduini, I. (2016). Forage and grain yield of common buckwheat in Mediterranean conditions: Response to sowing time and irrigation. Crop \& Pasture Science, 67, 1000-1008, https://doi.org/10.1071/CP16091

Meyer, R., Warren, L., Eckert, J., Hancock, D., Blount, A., \& Olson, C. (2010). Perennial peanut: Forage nutritional composition and feeding value. AN234, Animal Science Department, Florida Cooperative Extension Service, Institute of Food and Agricultural Sciences, University of Florida. Retrieved from http://edis.ifas.ufl.edu

Mu, C. T., Ding, N., Hao, X. Y., Zhao, Y. B., Wang, P. J., Zhao, J. X., ... Zhang, J. X. (2019). Effects of different proportion of buckwheat straw and corn straw on performance, rumen fermentation and rumen microbiota composition of fattening lambs. Small Ruminant Research, 181, 21-28, https://doi.org/10.1016/j.smallrumr es.2019.09.006

SAS. (2014). SAS for Windows Version 9.4. SAS Institute, Cary, N.C. Retrieved from http://www.sas.com/en_us/ software/sas9.html

\section{Copyrights}

Copyright for this article is retained by the author(s), with first publication rights granted to the journal.

This is an open-access article distributed under the terms and conditions of the Creative Commons Attribution license (http://creativecommons.org/licenses/by/4.0/). 